\title{
Bước đầu đánh giá tác động của tế bào gốc trung mô từ dây rốn trên mô hình chuột tổn thương gan do tắc mật
}

\section{Preliminary evaluating the effects of umbilical cord-derived mesenchymal stem cells on bile duct ligation induced liver injury mice}

\author{
Nguyễn Minh Thư ${ }^{1}$, Lê Văn Trình ${ }^{2}$, Đặng Minh Thành², Trương Hải Nhung ${ }^{2 *}$ \\ ${ }^{1}$ Trường Đại học Mở Thành phố Hồ Chí Minh, Việt Nam \\ ${ }^{2}$ Trường ĐH Khoa học Tự nhiên, Đại học Quốc gia TPHCM, Việt Nam \\ "Tác giả liên hệ, Email: thnhung@ @cmus.edu.vn
}

THÔNG TIN

DOI:10.46223/HCMCOUJS.

Ngày nhận: 09/04/2021

Ngày nhận lại: 10/05/2021

Duyệt đăng: 25/05/2021

Tư khóa:

chuột tắc mật, liệu pháp tế bào gốc, điều trị tắc mật, bệnh lý gan, bệnh hẹp đường mật

Keywords:

bile duct ligated mice, stem cell therapy, bile disease treatment, liver disease, biliary astresia
TÓM TẮT

Mục tiêu: Nghiên cứu này nhằm đánh giá tính an toàn và hiệu quả của tế bào gốc trung mô trên mô hình chuột tổn thương gan do tắc ống dẫn mật. Phương pháp: Chuột Swiss được tiến hành phẫu thuật thắt ống dẫn mật (BDL) để gây bệnh xơ gan. Sau BDL 7 ngày, chuột được tiêm tế bào gốc trung mô từ mô dây rốn (umbilical cord blood-derived - UCB-MSC) với liều $5 \times 10^{5}$ tb/con. Hiệu quả điều trị được đánh giá thông qua tỉ lệ sống chết, các chỉ số sinh hóa (AST, ALT, Albumin) và thay đổi cấu trúc mô học (nhuộm H\&E), sự tích lũy collagen trong mô gan (nhuộm Sirius Red), sự hoạt hóa tế bào hình sao (nhuộm hóa mô miễn dịch với marker $\alpha$-SMA). Kết quả: Sau 12 ngày điều trị, so với nhóm đối chứng-PBS, chuột tiêm MSC có tỉ lệ sống cao (100\%), giảm tổn thương gan (chỉ số sinh hóa men gan $\mathrm{Alb}, \mathrm{AST}$ và $\mathrm{ALT}$ trung bình lần lượt là $2.016 \mathrm{Dg} / \mathrm{L}, 432.9 \mathrm{UI} / \mathrm{L}$ và $417.7 \mathrm{UI} / \mathrm{L}$ ), giảm diện tích xơ gan thông qua diện tích hoại tử trung bình là $7.529 \%$, sự tích lũy collagen trong gan trung bình là $1.968 \%$ và tỷ lệ dương tính của protein $\alpha$-SMA là $1.42725 \%$. Kết luận: Bước đầu đánh giá được tính an toàn và hiệu quả điều trị chuột tổn thương gan do tắc ống dẫn mật bằng tế bào gốc trung mô (MSC).

\section{ABSTRACT}

Objective: The purpose of this research is to evaluate effective treatment of mesenchymal stem cells due to bile duct obstruction on mouse models with liver damage underwent bile duct ligation (BDL). Method: Swiss mice underwent bile duct surgery (BDL) to cause cirrhosis. After 7 days of BDL, mice were injected with mesenchymal stem cells isolated from umbilical cord blood-derived (UCB-MSC) at a dose of $5 \times 10^{5}$ cell/mice. Treatment efficacy was assessed through mortality, biochemical indices (AST, ALT, Albumin) and histological changes (H\&E staining), collagen accumulation in liver tissue (Sirious Red 
staining), astrocytes activation (immunohistochemistry with $\alpha$ SMA marker). Result: After 12 days of treatment, compared to the PBS-control group, mice injected with MSC had a high survival rate $(100 \%)$, reduced liver damage (average liver enzymes of Alb, AST and ALT, respectively 2.016 Dg/L, 432.9 $\mathrm{UI} / \mathrm{L}$ and $417.7 \mathrm{UI} / \mathrm{L}$,), reducing the area of cirrhosis through an average necrotic area of $7.529 \%$, the mean liver collagen accumulation $1.968 \%$, and the positive rate of $\alpha$-SMA protein is $1,42725 \%$. Conclusion: Initially assess the safety and treatment effectiveness with liver damage caused by bile duct obstruction by mesenchymal stem cells (MSC).

\section{Giới thiệu}

Tắc mật bẩm sinh hay thủng đường mật ở những trẻ sơ sinh dù hiếm gặp nhưng nếu không được phát hiện sớm và điều trị sẽ dần đến suy gan hay xơ gan (Bates, Bucuvalas, Alonso, \& Ryckman, 1998). Dữ liệu thống kê cho thấy tỉ lệ mắc bệnh ở các nước Châu Á cao hơn so với châu Âu và châu Mỹ, chẳng hạn như tỉ lệ mắc bệnh ở Mỹ là 1:19.000, ở Anh và các nước châu Âu 1:16.000, trong khi đó tỉ lệ mắc bệnh ở các nước châu Á như Nhật Bản và Trung Quốc khoảng 1:9.600, đặc biệt khá cao ở Việt Nam với tỉ lệ 1:2400 (T. Liu, Wang, Karsdal, Leeming, \& Genovese, 2012).

Khi ống dẫn mật bị tắt nghẽn thì dịch mật bị ứ đọng lại có thể gây ra các tình trạng bệnh lý nghiêm trọng như xơ gan, nhiễm trùng đường mật, nhiễm trùng máu... Tắc mật trong thời gian dài sẽ dẫn đến tình trạng gan bị xơ hóa, khi gan bị xơ hóa thì tổn thương gan lúc này sẽ thường không phục hồi (Nam, Ko, \& Sohn, 2019). Phương pháp điều trị hiện nay là tiến hành phẫu thuật Kasai (được phát triển bởi bác sĩ người Nhật, Morio Kasai). Phương pháp này giúp giảm bớt sự tắc mật bằng cách phẫu thuật nối hỗng tràng với nhánh nhỏ mật trong gan (portoentersstomy). Các trường hợp bệnh nhân không được tiến hành phẫu thuật thì sẽ tử vong trong vòng 2 năm, với thời gian sống trung bình là 8 tháng (Bates et al., 1998). Tuy nhiên sau khi tiến hành phẫu thuật Kasai, bệnh nhân vẫn cần phải tiến hành ghép gan. Tỷ lệ sống sót sau 5 năm không ghép gan thay đổi từ $32 \%$ đến $63 \%$ và tỷ lệ phẫu thuật Kasai thất bại cao $(62 \%)$ (Shinkai et al., 2009). Mặc dù có nhiều tác dụng phụ, nhưng kháng sinh, thuốc vận mật (choleretics) và steroid thường được chỉ định sau phẫu thuật Kasai. Bệnh nhi bị hẹp đường mật bẩm sinh cần kiểm soát tình trạng suy gan mật để chuẩn bị cho việc ghép gan sau đó. Tình trạng khan hiếm nguồn tạng ghép và thời gian sống sót của bệnh nhi sau phẫu thuật Kasai là thách thức lớn của y khoa.

\section{Cơ sở lý thuyết}

Tế bào gốc trung mô (Mesenchymal stem cell- MSC) là tế bào gốc trưởng thành đa chức năng có thể được phân lập từ nhiều nguồn khác nhau như từ tủy xương (bone marrow), dây rốn (umbilical cord), mô mõ̃ (adipose tissue), nội mạc tử cung (endometrium), nước ối (amniotic fluid), mô răng (dental tissue) (Ullah, Subbarao, \& Rho, 2015). MSC có khả năng tăng sinh và biệt hóa thành nhiều loại tế bào, lợi thế của MSC là có thể thu nhận dễ dàng, có các đặc tính điều hòa miễn dịch, sản sinh các chất tiết như các yếu tố tăng trưởng, cytokine giúp cho MSC trở thành công cụ hiệu quả để điều trị các bệnh viêm mạn tính (Ullah et al., 2015). Ngoài ra, MSC còn có khả năng đi đến mô tổn thương, ngăn chặn các phản ứng viêm, giảm "apotosis" tế bào gan, tăng tái tạo tế bào, hồi phục xơ gan và tăng cường chức năng gan (Kyung Ah Cho et 
al., 2009; Kyung-Ah Cho, Woo, Seoh, Han, \& Ryu, 2012). Tế bào gốc được phân lập từ dây rốn (UCB-MSC) (M. B. Liu et al., 2017; Lou, Chen, Zheng, \& Liu, 2017) có tỷ lệ tăng sinh tế bào cao và sự biểu hiện các dấu hiệu lão hóa thấp hơn đáng kể so với các nguồn thu nhận từ tủy xương hay mô mỡ. Ngoài ra UCB-MSC còn có khả năng chống viêm cao hơn so với nguồn thu nhận từ tuỷ xương hay mỡ, nên UCB-MSC trở thành một mô hình hữu ích cho các ứng dụng lâm sàng của liệu pháp tế bào như liệu pháp điều trị viêm gan (Eom, Shim, \& Baik, 2015; Jin et al., 2013; Lou et al., 2017; Wang, Yuan, \& Xie, 2018). Ngoài ra, MSC có khả năng điều hòa miễn dịch, tương tác với hàng rào miễn dịch do có thể hoạt động như những tế bào trình diện kháng nguyên nên giúp giảm thiểu thải ghép với vật chủ cũng là mối quan tâm của các nhà khoa học (Castillo, Liu, Bonilla, \& Rameshwar, 2007). Vì MSC có tiềm năng biệt hóa thành tế bào gan (Ullah et al., 2015), giảm viêm gan và thúc đẩy tái tạo gan (Kyung Ah Cho et al., 2009) nên đây sẽ là con đường phát triển đầy tiềm năng cho việc điều trị bệnh lý gan. Tại Việt Nam, một số công trình nghiên cứu sử dụng MSC để điều trị bệnh xơ gan như: sử dụng tế bào gốc trung mô từ tủy xương để đánh giá hiệu quả điều trị xơ gan trên mô hình chuột $\mathrm{CCl}_{4}(\mathrm{~N}$. $\mathrm{H}$. Truong, Trình, et al., 2016) hay MSC từ mô mỡ người kết hợp huyết tương giàu tiểu cầu và yếu tố tăng trưởng tế bào gan làm giảm xơ hóa gan ở chuột $\mathrm{CCl}_{4}(\mathrm{~N}$. H. Truong, Nguyen, et al., 2016); hay sử dụng tế bào gốc tủy xương tự thân trong điều trị xơ gan mất bù do virus viêm gan B (G. D. Truong et al., 2018). Hiện chưa có nhiều nghiên cứu tiếp cận điều trị tổn thương gan do tắc mật trên chuột thực nghiệm bằng liệu pháp tế bào gốc. Do đó trong nghiên cứu này, chúng tôi bước đầu đánh giá tính an toàn và hiệu quả của liệu pháp ghép tế bào gốc trung mô từ mô dây rốn (UCB-MSC) $\left(5 \times 10^{5}\right.$ tb/con) trên mô hình chuột Swiss tổn thương gan do tắc mật nhằm chỉ ra tiềm năng điều trị của tế bào trên bệnh lý tắc mật nói riêng và tổn thương gan nói chung.

\section{Phương pháp nghiên cứu}

\section{1. Đối tuợng thí nghiệm}

Chuột Swiss 6-8 tuần tuổi trọng lượng 25-30g (do Phòng thí nghiệm chăm sóc và sử dụng Động vật, Viện tế bào gốc, trường ĐH Khoa học Tự nhiên, ĐH Quốc gia TPHCM cung cấp) được phẫu thuật thắt ống dẫn mật (BDL) để tạo mô hình tổn thương gan do tắc ống dẫn mật. Sau 7 ngày chuột có biểu hiện vàng tai, vàng đuôi sẽ được phân thành 2 nhóm thí nghiệm (đối chứng tiêm PBS, ghép tế bào gốc UCB-MSC được cung cấp bởi Viện tế bào gốc, Trường ĐH Khoa học tự Nhiên, ĐH Quốc gia TPHCM với liều $5 \times 10^{5}$ tế bào/con).

\subsection{Tạo mô hình chuột tổn thwơng do tắc ống dẫn mật bằng phuơng pháp phẫu thuật thắt ống dẫn mật (BDL)}

Chuột nhịn đói 1 giờ trước khi tiến hành phẫu thuật thắt ống dẫn mật. Sau khi gây mê (hỗn hợp thuốc mê Xylazine - Zoletil), cố định chuột trên khay, cạo lông và khử trùng vùng bụng bằng thuốc sát khuẩn Povidine, tiến hành mở khoang bụng ngay vị trí ống mật chủ, dưới cơ hoành. Xác định ống mật chủ, dùng chỉ vô trùng thắt chặt ống mật chủ ở 2 vị trí một là vùng gần cửa gan và một ở vùng gần tá tràng (Hình 1$)$. Mục đích của phương pháp này là gây tắc ống dẫn mật làm mật bị ứ đọng trong gan, mô phỏng lại bệnh lý tắc mật ở người. 


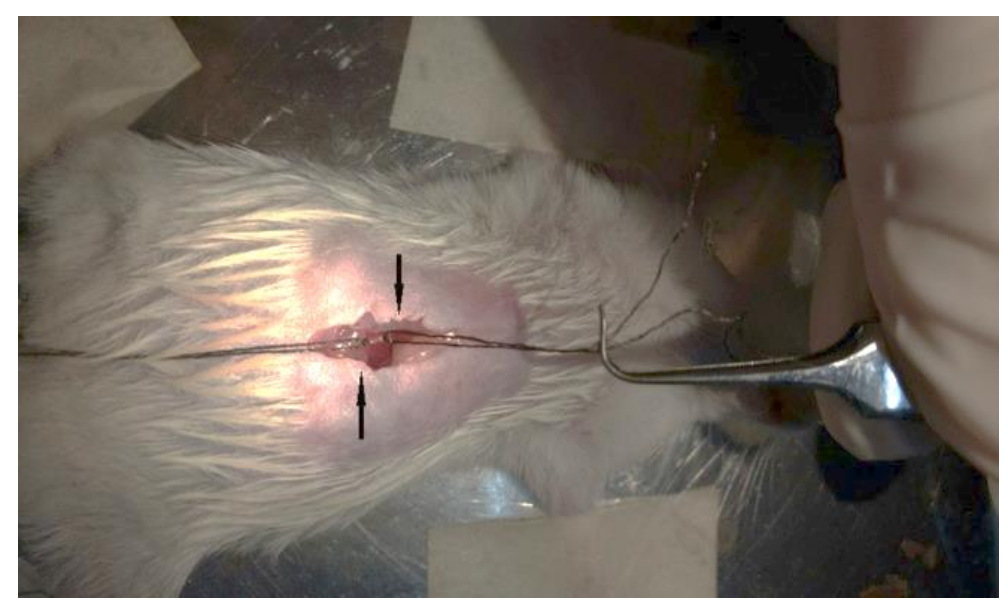

Hình 1. Phẫu thuật thắt ống dẫn mật (BDL) ở chuột Swiss

\subsection{Tiêm MSC}

Chuột sau BDL 7 ngày được tiêm $1 \mathrm{ml}$ dịch huyền phù UCB-MSC (nồng độ $5 \times 10^{5}$ tb/con) trong Ringer Lactat vào tĩnh mạch đuôi.

\section{4. Đánh giá tỷ lệ sống sót, sụ thay đổi khối lự̛ng cơ thể và gan}

Chuột được theo dõi về tình trạng sống/chết hằng ngày và cân đo khối lượng cơ thể theo các mốc 3 ngày, 7 ngày, 19 ngày. Khối lượng gan được cân ở ngày thứ 19 sau BDL để tiến hành đánh giá.

\section{5. Đánh giá chỉ số bạch cầu để xác định tình trạng viêm ở chuột tổn thương gan}

Máu tĩnh mạch được thu nhận và chuẩn bị tiêu bản máu trên lame, để tiêu bản khô tự nhiên, cố định bằng cồn và nhuộm với thuốc nhuộm Giemsa để xác định công thức bạch cầu.

Để xác định số lượng bạch cầu tổng, máu được trộn trong ống trộn bạch cầu và đếm số lượng trên buồng đếm.

\section{6. Định lự̛ng các chỉ số sinh hóa máu để đánh giá chức năng gan}

Huyết thanh chuột được chuẩn bị từ $500 \mu 1$ máu theo quy trình đông máu tự nhiên trong 1 giờ và ly tâm ở 3000rpm/30 phút để thu phần huyết thanh. AST (Aspartate transaminase), ALT (Alanine tranaminase) trong huyết thanh được xác định bằng bộ kit SGOT/SGPT (HUMAN Diagnostics, Germany) theo hướng dẫn của nhà sản xuất và máy đọc đĩa DTX 880 Multidector ở bước sóng 340nm. Albumin trong huyết thanh được xác định bằng bộ KIT QuantiChrom TM BCG Albumin Assay kit (BioAssay Systems, USA) theo hướng dẫn của nhà sản xuất và máy đọc đĩa DTX 880 Multidector ở bước sóng 620nm.

\section{7. Đánh giá mô học}

\subsubsection{Nhuộm Hematoxylin và Eosin để đánh giá vùng viêm và hoại tử}

Lát cắt mô được khử parafin sau đó nhuộm với Hematoxylin và Eosin. Hình ảnh mô học được chụp bằng kính hiển vi AxioVision. Các vùng hoại tử được xác định bằng cách khoanh vùng trên hình chụp bằng phần mềm Axio Vision SE64 Rel.4.9.1. Việc đo và tính toán vùng hoại tử được tiến hành theo phương pháp mù (blinded).

3.7.2. Nhuộm Sirius Red để đánh giá sụ tích luỹ collagen trong gan 
Lát cắt mô được khử parafin sau đó nhuộm với thuốc nhuộm Picrosirius Red F3B (PolyScience, Mỹ) theo hướng dẫn của nhà sản xuất. Các vùng bắt màu đỏ của thuốc nhuộm là vùng dương tính collagen. Hình ảnh được chụp bằng kính hiển vi Axio Vision. Tỉ lệ diện tích vùng dương tính colagen được tính bằng phần mềm ImageJ.

3.7.3. Nhuộm hóa mô miễn dịch (IHC) để đánh giá các protein gây viêm gan, xơ gan

Lát cắt mô gan được khử paraffin và phục hồi kháng nguyên bằng dung dịch đệm Tris EDTA $(\mathrm{pH}=9)$. Nhuộm IHC theo quy trình của nhóm nghiên cứu (N. H. Truong, Trình, et al., 2016) và nhân tế bào được nhuộm với Hematoxylin (Merck Millipore, Đức). Tỉ lệ diện tích vùng dương tính colagen được tính bằng phần mềm ImageJ.

\subsection{Phương pháp thống $k \hat{e}$}

Các số liệu trong thí nghiệm được xử lý bằng phần mềm GraphPad Prism 8: Phương pháp thống kê student t-test. Khác biệt có ý nghĩa thống kê khi palue $\leq 0.05$.

\section{Kết quả nghiên cứu}

4.1. Kết quả tạo mô hình chuột tổn thuơng do tắc ống dẫn mật bằng phương pháp phẫu thuật thắt ống dẫn mật (BDL)

\subsubsection{Biểu hiện hình thái bên ngoài}

Kết quả thí nghiệm thắt ống dẫn mật tạo ra sự tắc nghẽn dòng chảy của mật xuống ruột non khiến cho túi mật căng to do tích lũy các acid/muối mật. Chuột sau BDL thành công sẽ có các biểu hiện rõ rệt về hình thái của bệnh lý viêm gan như vàng da (tai và đuôi) (Hình $2 \mathrm{~B}$ ) và sụt cân.

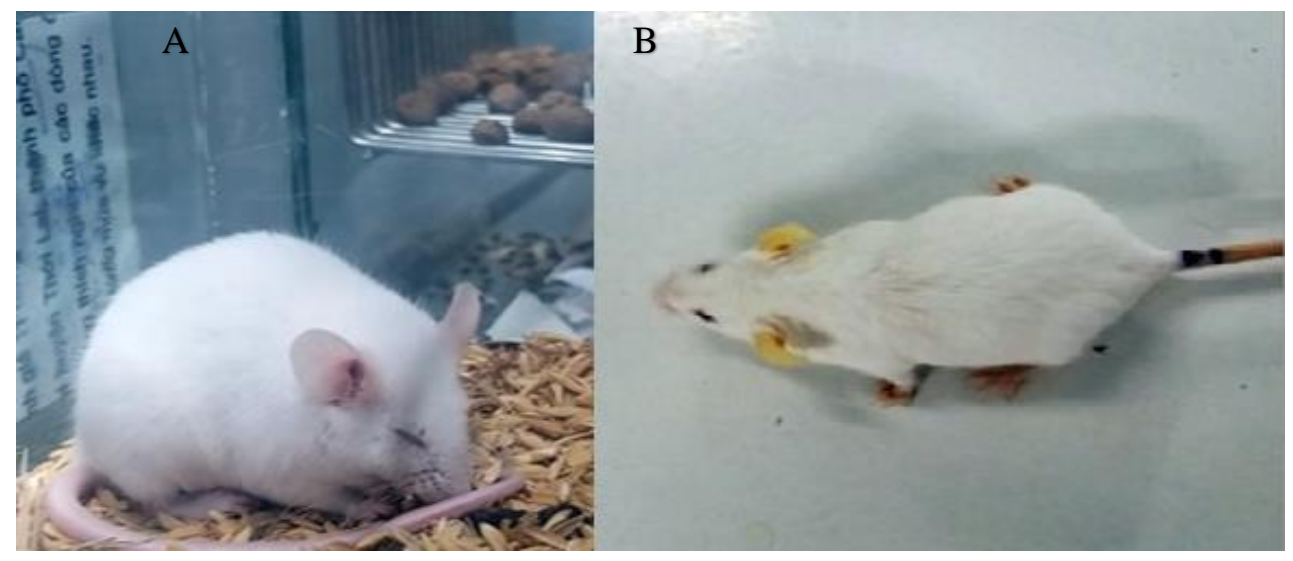

Hình 2. So sánh hình thái bên ngoài của chuột thường (Normal) và chuột BDL sau 19 ngày

A: Chuột Normal tai, đuôi màu trắng

B: Chuột BDL có tai, đuôi màu vàng

4.1.2. Đánh giá tỷ lệ sống chết ở mô hình chuột thắt ống dẫn mật 


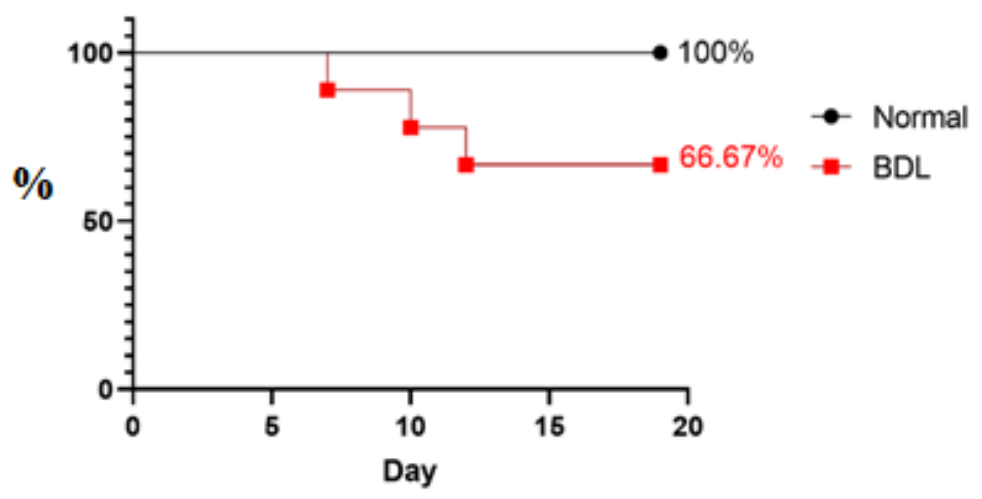

Biểu đồ 1. Tỉ lệ sống chết giữa nhóm Normal và nhóm $\mathrm{BDL}$

Từ biểu đồ 1 cho thấy tỉ lệ sống của nhóm chuột Normal là $100 \%$ trong khi nhóm BDL chỉ $66.67 \%$ sau 19 ngày thắt ống mật. Điều này chứng tỏ thắt ống dẫn mật gây tổn thương gan dẫn tới tử vong ở chuột Swiss.

\subsubsection{Kết quả sự thay đổi khối lượng co thể và gan}
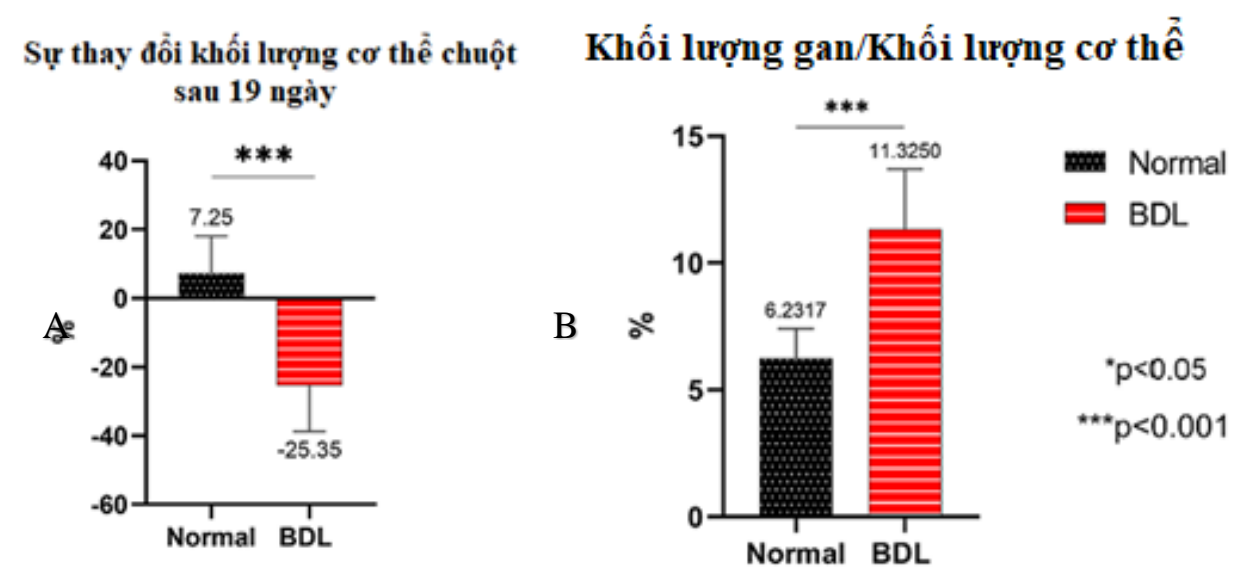

Biểu đồ 2. Sự thay đổi khối lượng cơ thể và gan giữa nhóm Normal và nhóm BDL

Biểu đồ 2 cho thấy chuột bình thường (Normal) tăng cân còn chuột tổn thương do tắc ống dẫn mật $(\mathrm{BDL})$ thì bị sụt cân $(\mathrm{p}<0.001)$. Chuột bị tổn thương gan có sự thay đổi về cân nặng so với chuột bình thường.

Khối lượng gan ở chuột Normal nhỏ hơn so với chuột BDL ( $\mathrm{p}<0.001)$ (biểu đồ 2).

4.1.4. Kết quả đánh giá chỉ số bạch cầu xác định tình trạng viêm ở chuột tổn thuơng 


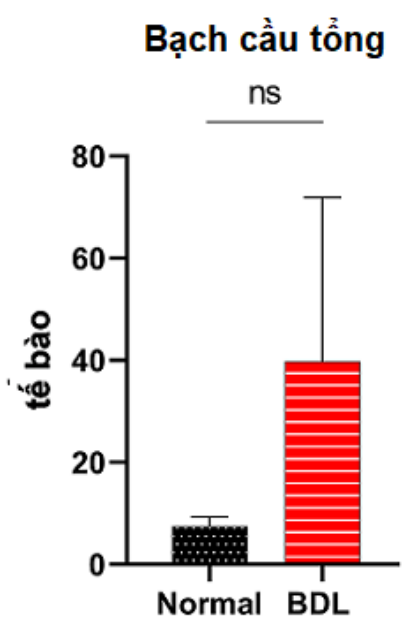

Tỷ lệ bạch cầu trung tính

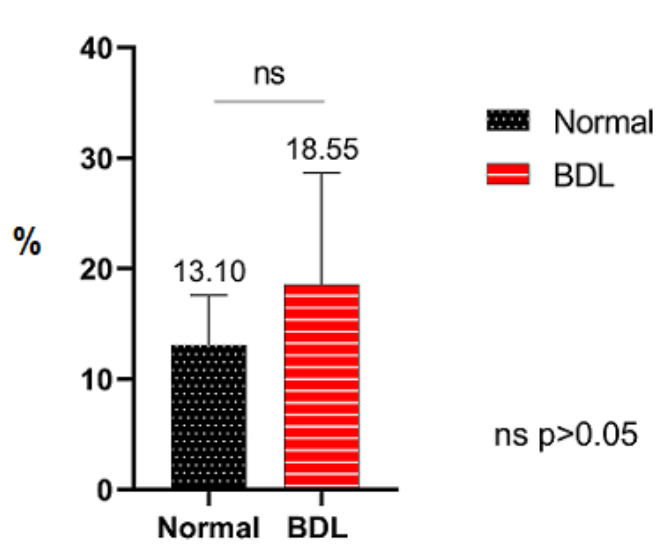

Biểu đồ 3. So sánh bạch cầu giữa nhóm Normal và nhóm BDL sau 19 ngày thắt ống dẫn mật

Nhóm chuột BDL có tỉ lệ bạch cầu tổng và bạch cầu trung tính tăng cao hơn so với Normal ( $\mathrm{p}>0.05)$ (Biểu đồ 3 ) chứng tỏ nhóm chuột BDL có xuất hiện phản ứng viêm.

\subsubsection{Kết quả định lượng các chỉ số sinh hóa máu}
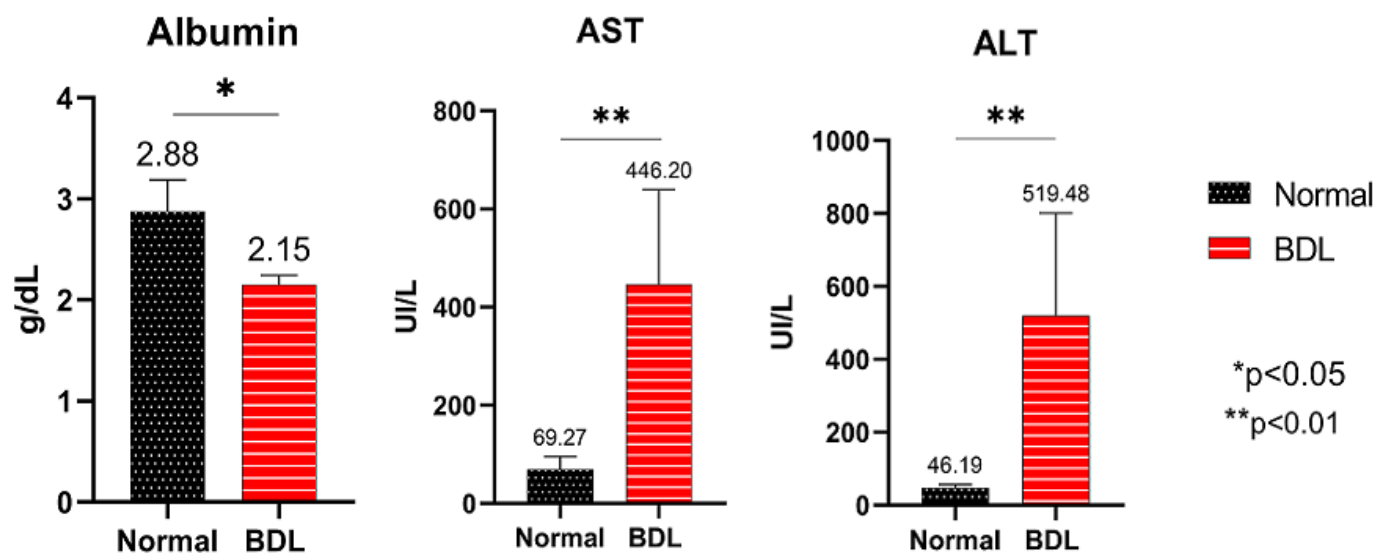

Biểu đồ 4. Chỉ số sinh hóa máu giữa nhóm Normal và nhóm BDL

Kết quả ghi nhận cho thấy men gan AST/ALT tăng cao ở nhóm BDL so với nhóm Normal $(\mathrm{p}<0.01)$ (Biểu đồ 4).

Albumin trên nhóm chuột BDL giảm so với chuột Normal ( $\mathrm{p}<0.05)$ (Biểu đồ 4).

4.1.6. Kết quả đánh giá mô học

- Kết quả nhuộm Hematoxylin và Eosin 

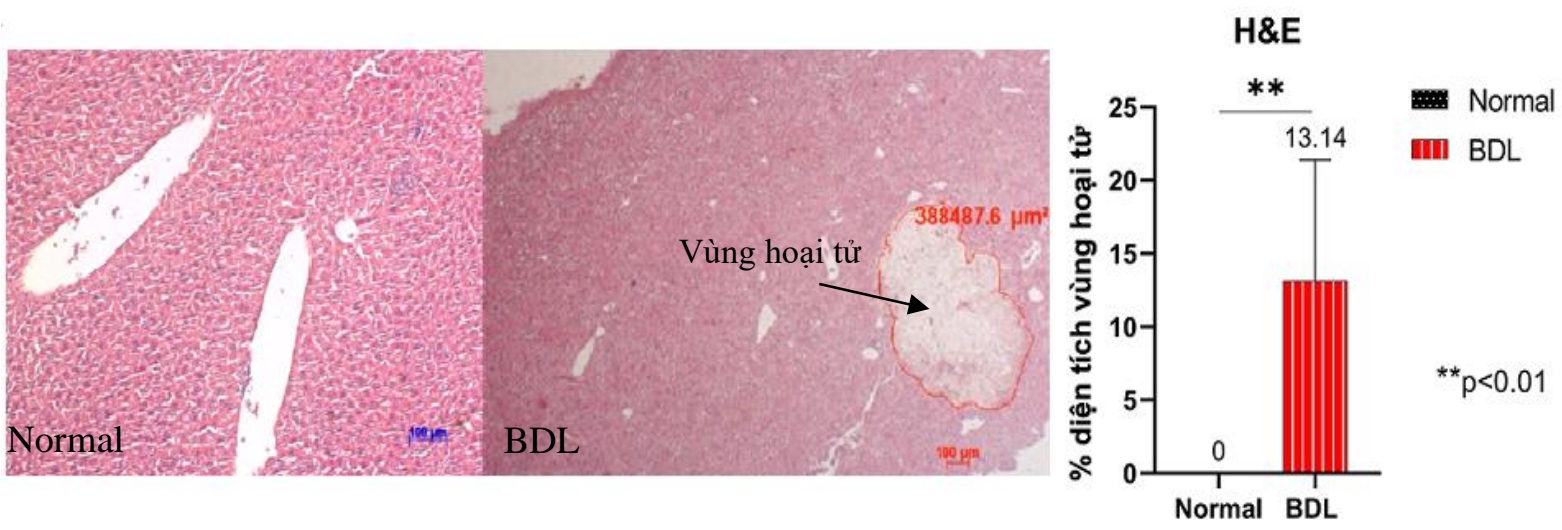

Hình 3. Kết quả nhuộm H\&E giữa nhóm Normal và nhóm BDL.

Kết quả mô học cho thấy, gan chuột BDL xuất hiện tình trạng viêm và hoại tử (Hình 3 ). Kết quả này khác biệt so với Normal $(\mathrm{p}<0.01)$.

- Kết quả nhuộm Sirius Red
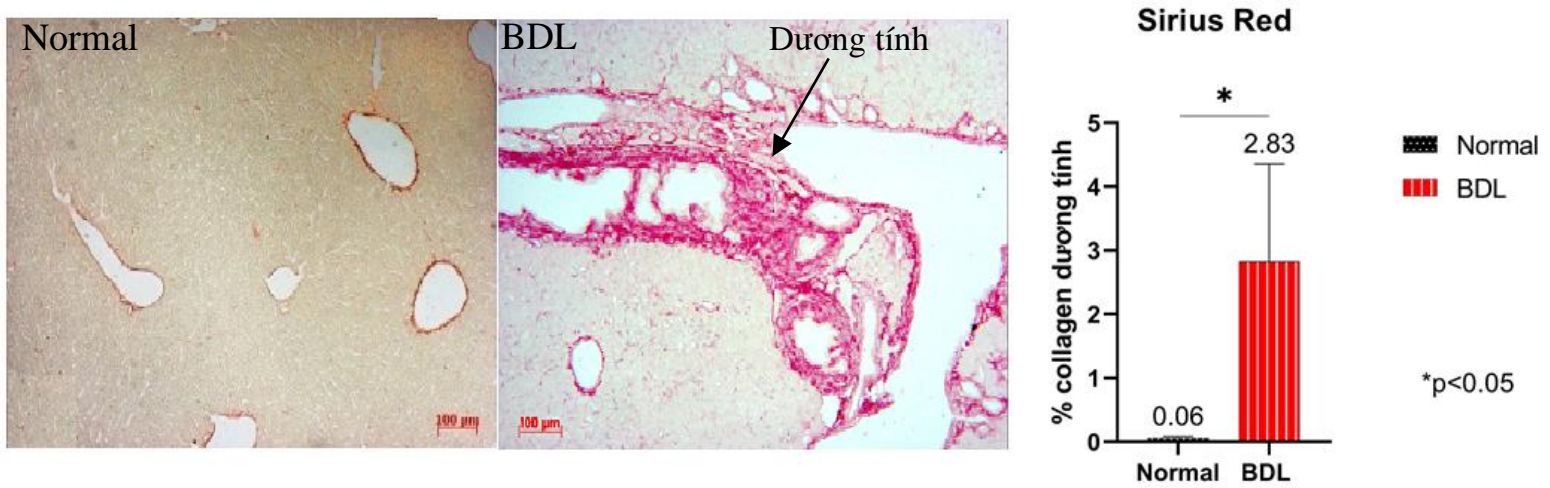

Hình 4. Kết quả nhuộm Sirius Red giữa nhóm Normal và nhóm BDL

Kết quả nhuộm collagen cho thấy nhóm BDL có các dãy xơ ở vùng có cấu trúc ống mật. Kết quả này khác biệt với nhóm Normal ( $\mathrm{p}<0.05)$.

- Kết quả nhuộm hóa mô miễn dịch (IHC) để đánh giá các protein gây viêm gan, xơ gan - $\alpha$-SMA
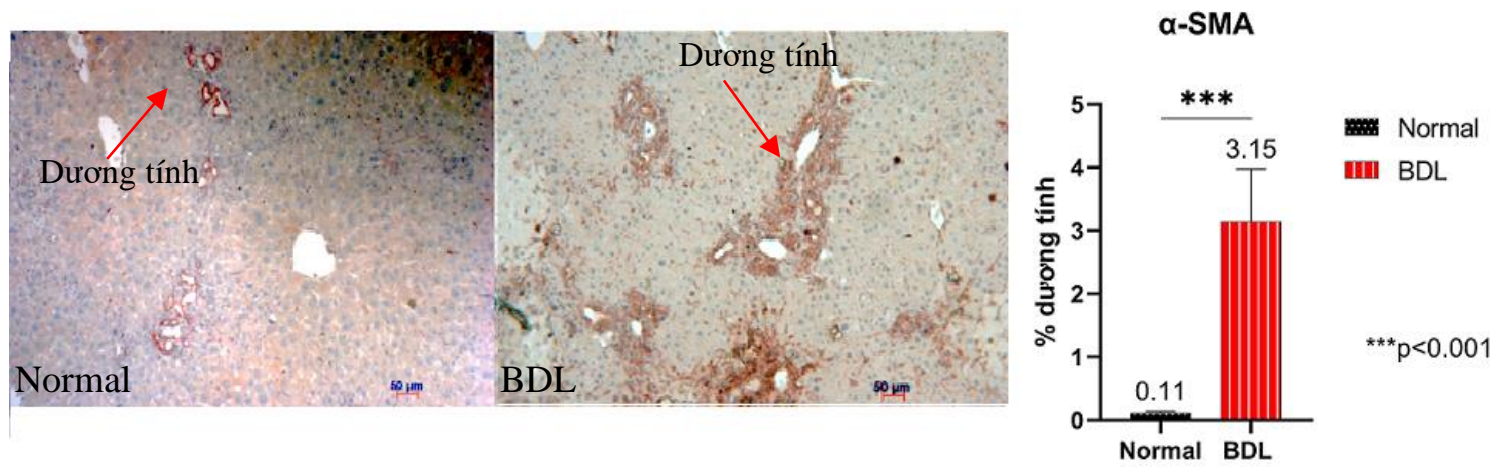

Hình 5. Kết quả nhuộm $\alpha$-SMA giữa nhóm Normal và nhóm BDL 
Kết quả nhuộm IHC mô gan với kháng thể là $\alpha$-SMA cho thấy nhóm BDL xuất hiện nhiều vùng dương tính với $\alpha$-SMA khác biệt có ý nghĩa thống kê so với nhóm Normal $(\mathrm{p}<0.001)$.

4.2. Kết quả đánh giá tính an toàn và hiệu quả điều trị bằng MSC cho chuột bị tổn thưong gan do tắc ống dẫn mật

4.2.1. Ghép UCB-MSC cải thiện biểu hiện hình thái bên ngoài và gan chuột BDL

Chuột sau khi ghép tế bào gốc 12 ngày, có giảm vàng da (đuôi, tai), lông mượt (hình 6).

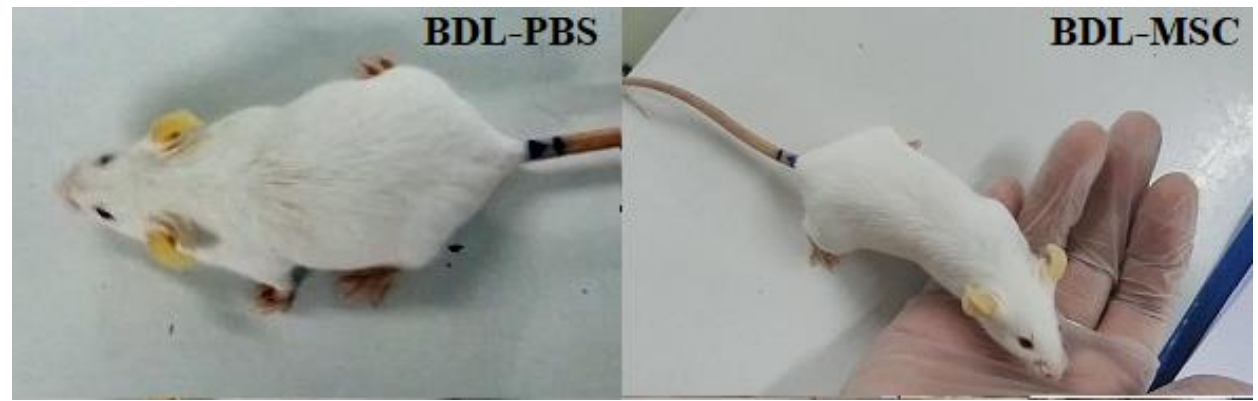

Hình 6. Chuột nhóm đối chứng (BDL-PBS) và nhóm tiêm MSC (BDL-MSC)

Sau 12 ngày, nhóm BDL-PBS xuất hiện các mảng xơ gan, gan nhạt màu trong khi nhóm BDL-MSC thì đại thể gan đồng nhất màu đỏ đậm, ngoại trừ túi mật to thì không thấy rõ các mảng xơ (Hình 7).

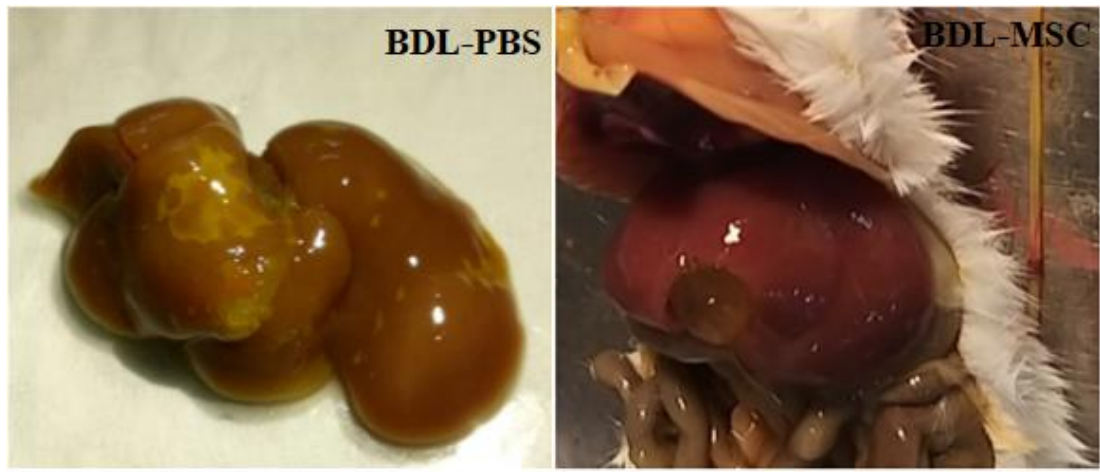

Hình 7. So sánh gan của chuột BDL-PBS và nhóm BDL-MSC

4.2.2. Ghép UCB-MSC cải thiện tỷ lệ sống chết ở mô hình chuột thắt ống dẫn mật

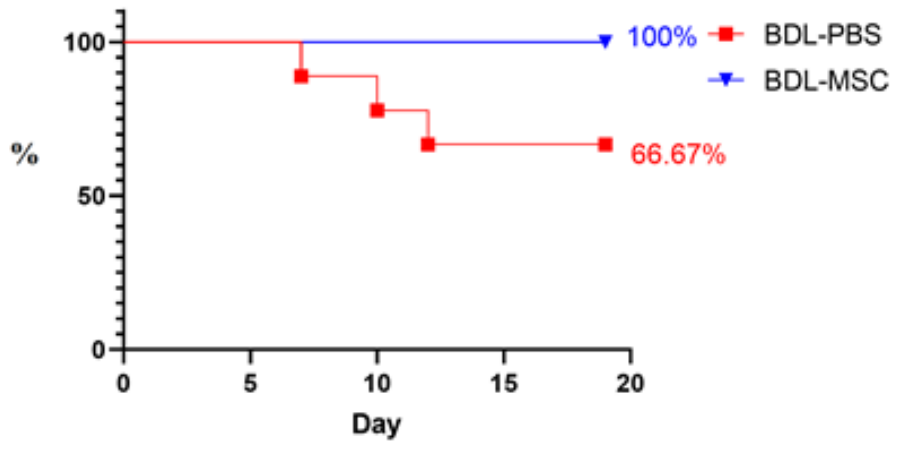

Biểu đồ 5. Tỉ lệ sống chết giữa nhóm BDL-PBS và nhóm BDL-MSC 
Từ biểu đồ 5 cho thấy tỉ lệ sống chết của nhóm chuột BDL-MSC có tỉ lệ sống cao (100\%) hơn nhóm BDL-PBS (66.67\%) sau 19 ngày.

\subsubsection{Sự thay đổi khối lượng cơ thể và khối lượng gan}

\section{Sự thay đổi khối lượng chuột sau 19 ngày}

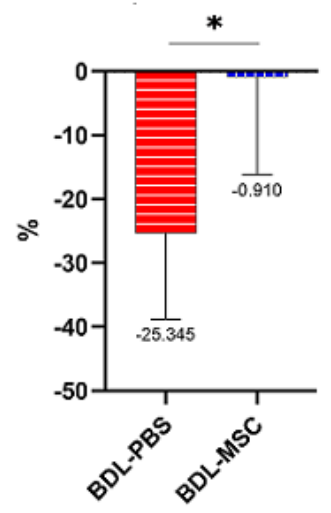

Sự thay đổi khối lượng chuột · Khối lượng gan/Khối lượng cở thể sau khi tiêm MSC

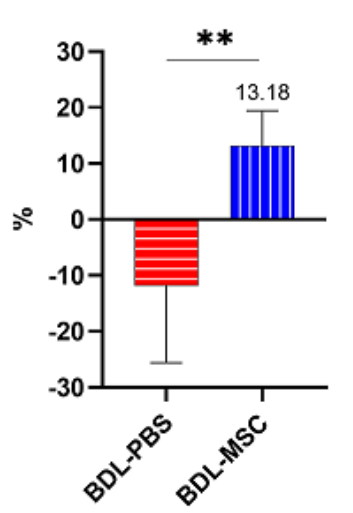

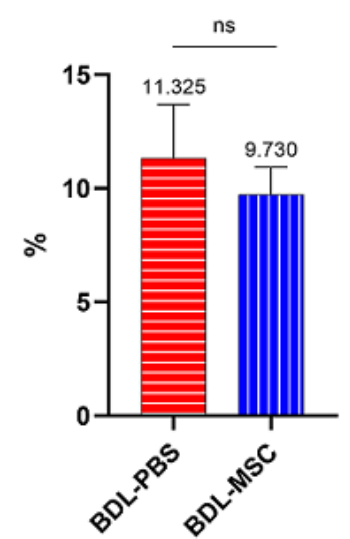

= BDL-PBS

IIII BDL-MSC

ns $p>0.05$

${ }^{*} p<0.05$

${ }^{* *} p<0.01$

Biểu đồ 6. Sự thay đổi khối lượng cơ thể và \% gan so với khối lượng cơ thể giữa nhóm BDL$\mathrm{PBS}$ và nhóm BDL-MSC

Biểu đồ 6 cho thấy nhóm BDL-MSC cải thiện cân nặng tốt hơn so với nhóm BDL-PBS tại thời điểm sau ghép 12 ngày $(\mathrm{p}<0.01)$. Kết quả tại thời điểm 19 ngày sau $\mathrm{BDL}$, cả 2 nhóm chuột đều giảm khối lượng, tuy nhiên nhóm BDL-PBS giảm khối lượng nhiều hơn so với nhóm BDL-MSC $(p<0.05)$

Kết quả ghi nhận khối lượng gan trên 2 nhóm chuột không có sự khác biệt ý nghĩa thống kê ( $\mathrm{p}>0.05)$, mặc dù nhóm BDL-MSC có khối lượng gan trung bình thấp hơn so với nhóm BDL-PBS.

\subsubsection{Kết quả đánh giá chỉ số bạch cầu}

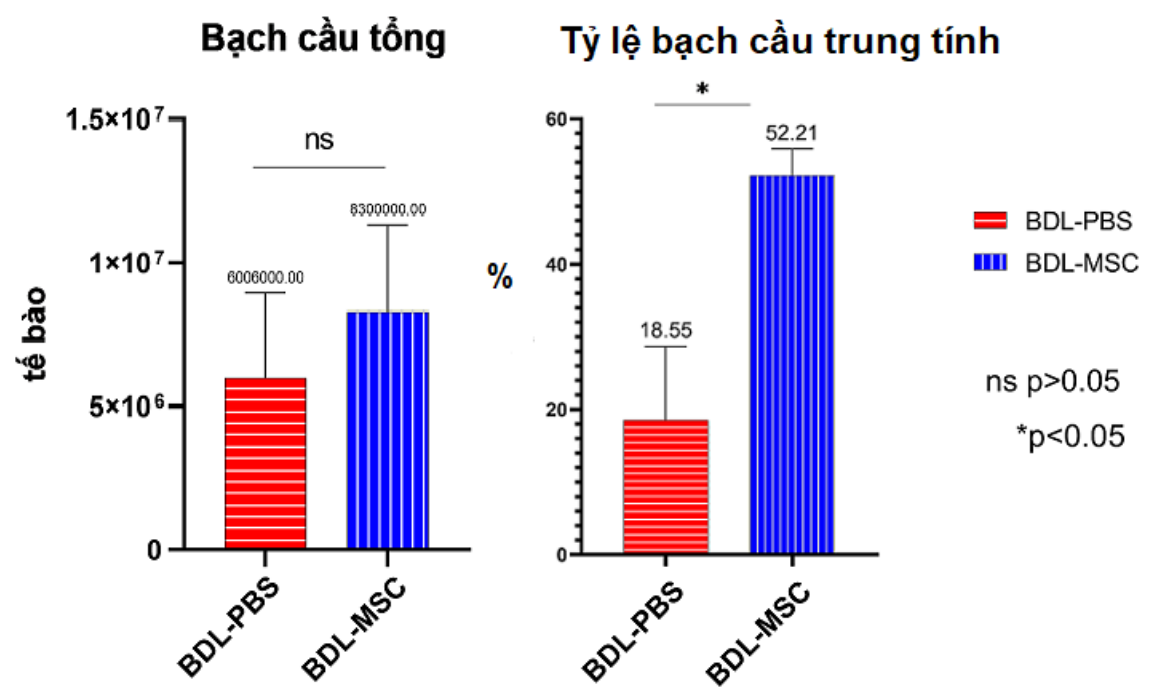

Biểu đồ 7. So sánh bạch cầu giữa nhóm BDL-PBS và nhóm BDL-MSC 
Kết quả từ biểu đồ 7 sự thay đổi bạch cầu tổng không khác biệt có ý nghĩa trên 2 nhóm thí nghiệm $(\mathrm{p}>0.05)$, trong khi đó nhóm BDL-PBS phục hồi số lượng bạch cầu trung tính $(\mathrm{p}<0.05)$.

\subsection{5. Định lượng các chỉ số sinh hóa máu}
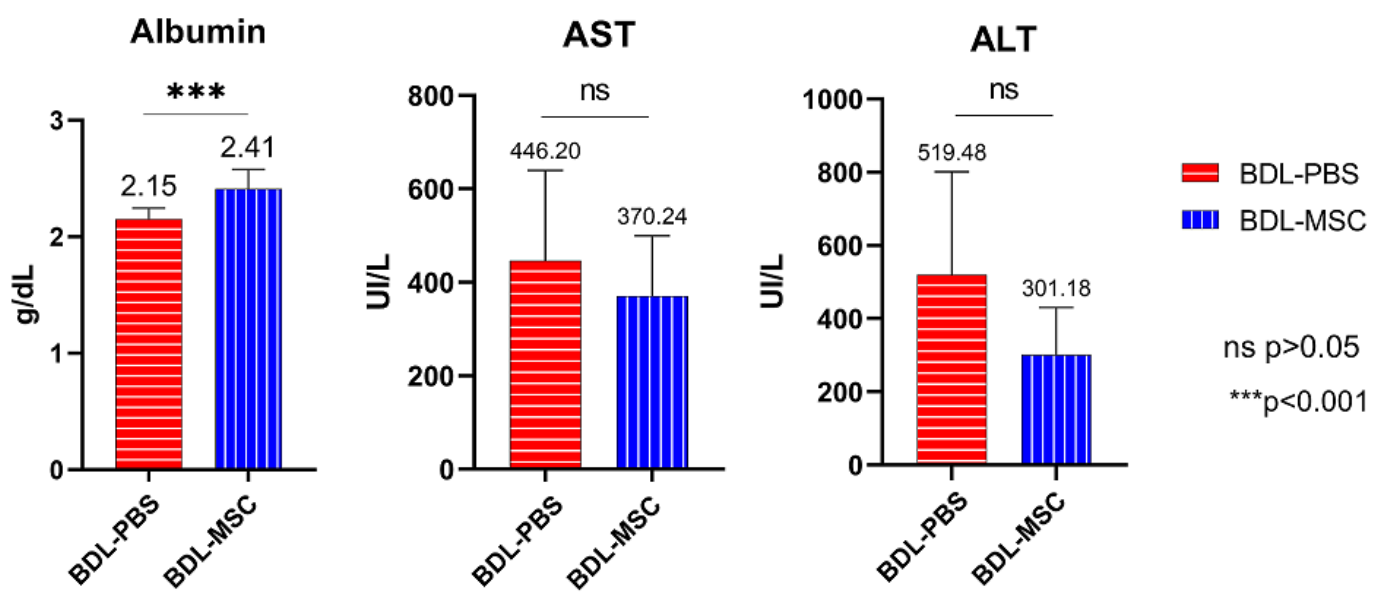

Biểu đồ 8. Chỉ số sinh hóa máu giữa nhóm BDL-PBS và nhóm BDL-MSC

Kết quả các chỉ số sinh hóa máu (Biểu đồ 8), men gan AST/ALT ở nhóm BDL-PBS ở mức cao so với nhóm BDL-MSC, tuy nhiên kết quả khác biệt này không có ý nghĩa thống kê ( $\mathrm{p}>0.05)$. Trong khi đó, chỉ số Albumin nhóm BDL-MSC cải thiện tốt hơn so với nhóm chuột BDL-PBS $(\mathrm{p}<0.001)$, kết quả này cho thấy nhóm chuột BDL-MSC phục hồi chức năng sản xuất Albumin ở gan.

\subsubsection{Kết quả đánh giá mô học}

- Kết quả nhuộm Hematoxylin và Eosin
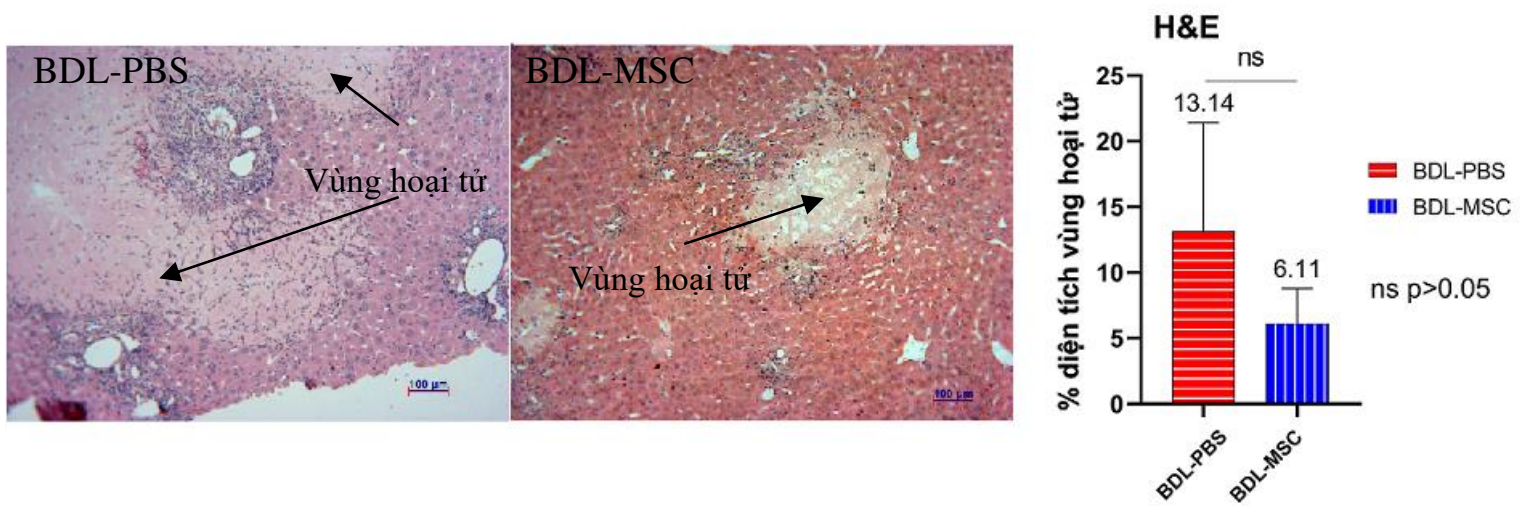

Hình 8. Kết quả nhuộm H\&E giữa nhóm BDL-PBS và nhóm BDL- MSC

Kết quả nhuộm H\&E cho thấy diện tích hoại tử ở gan trên nhóm BDL-MSC có cải thiện so với nhóm BDL-PBS, khác biệt này không có ý nghĩa thống kê (p>0.05).

- Nhuộm Sirius Red để đánh giá lượng collagen trong gan 

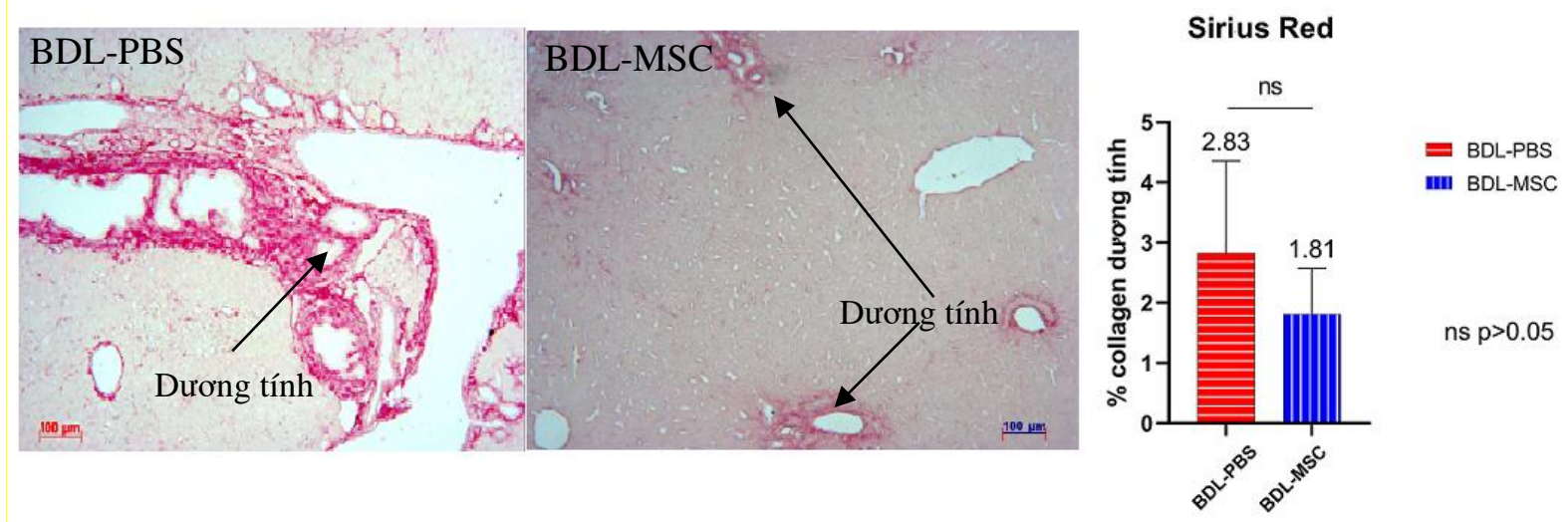

Hình 9. Kết quả nhuộm Sirius Red giữa nhóm BDL-PBS và nhóm BDL-MSC

Kết quả nhuộm Sirius Red (Hình 9) cho thấy nhóm BDL-PBS có các dãy xơ lan rộng ở vùng có cấu trúc ống mật trong khi các dãy xơ này giảm đáng kể ở nhóm BDL-MSC, điều này cho thấy sự cải thiện hình thành collagen trên nhóm BDL-MSC, khác biệt này không có ý nghĩa thống kê ( $\mathrm{p}>0.05)$.

- Kết quả nhuộm hóa mô miễn dịch (IHC)

- $\alpha$-SMA
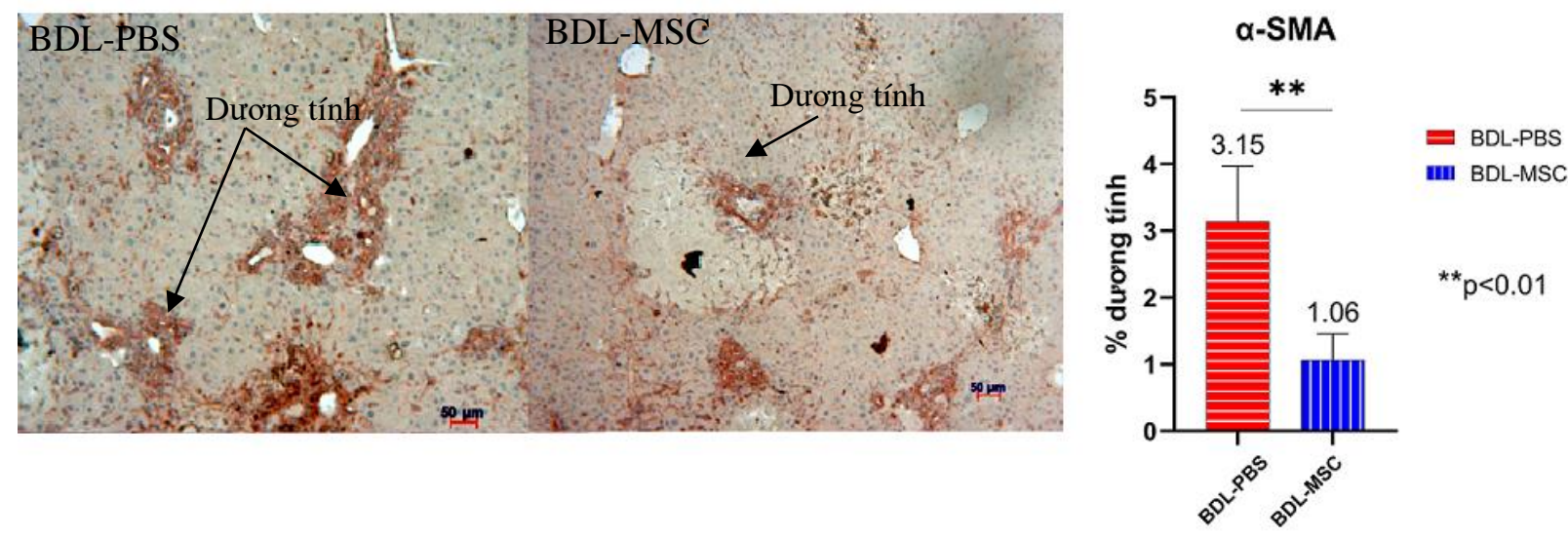

Hình 10. Kết quả nhuộm $\alpha$-SMA giữa nhóm BDL-PBS và nhóm BDL-MSC

Kết quả nhuộm IHC với kháng thể là $\alpha$-SMA cho thấy nhóm BDL-MSC có ít vùng dương tính protein $\alpha$-SMA hơn so với nhóm BDL-PBS ( $\mathrm{p}<0.01$ ), việc ghép MSC có tác dụng hạn chế sự biểu hiện $\alpha$-SMA trên HSC (tế bào hình sao gan)

\subsubsection{Bàn luận}

Phẫu thuật BDL gây ra sự ứ mật trong gan, mật không xuống ruột gây ra sự thiếu hụt dinh dưỡng, túi mật căng phồng chứa dịch mật bên trong, tăng nồng độ bilirubin trong máu gây hiện tượng vàng da, nước tiểu vàng, phân bạc màu. Mật ứ đọng gây chết tế bào gan, viêm vùng cửa, tăng sinh mạnh mẽ của các tế bào đường mật dẫn đến phản ứng ống dẫn mật (nhuộm $\mathrm{H} \& \mathrm{E}$ ), sự hoạt hóa của các tế bào hình sao sản xuất chất nền ngoại bào gây xơ hóa (nhuộm Sirius Red). Thắt ống mật chủ (BDL) là một mô hình thực nghiệm thích hợp để nghiên cứu đánh giá cơ chế sinh lý bệnh và điều trị xơ gan ứ mật. Mặc dù cơ chế xơ hóa ở gan ứ mật rất 
phức tạp, nhưng người ta đã xác định rõ rằng sự tích tụ của muối mật độc và kỵ nước trong gan, làm thay đổi cân bằng oxy hóa có lợi cho sự gia tăng hoạt động của các loại oxy phản ứng (ROS) và các chất tự do thúc đẩy phản ứng viêm, kích hoạt tế bào hình sao sản sinh collagen gây xơ gan. Stress oxy hóa trong bệnh gan ứ mật đóng vai trò là mối liên hệ giữa tổn thương gan và xơ hóa gan ở cả người và động vật (Ale-Ebrahim, Mahsa Eidi, Akram Mortazavi, Pejman Tavangar, \& Minai, 2015).

Kết quả biểu hiện ứ mật trong nghiên cứu của chúng tôi tương đồng với các công bố: Tag và cộng sự năm 2015 (Tag et al., 2015), Garrido và cộng sự năm 2017 (Garrido et al., 2017), Yang và cộng sự năm 2015 (Yang et al., 2015). Tại thời điểm 7 ngày sau phẫu thuật $\mathrm{BDL}$, sự giảm khối lượng cơ thể chuột cùng xu hướng với công bố của Garrido và cộng sự (2017) (Garrido et al., 2017), Ale-Ebrahim và cộng sự (2015) (Ale-Ebrahim et al., 2015). Ở chuột bình thường và chuột cống khỏe mạnh, khối lượng gan/khối lượng cơ thể có tỷ lệ 4.5$5 \%$. Sự tắc nghẽn ống dẫn mật có liên quan đến tăng áp lực tĩnh mạch cửa gây lách to (Kountouras, Billing, \& Scheuer, 1984).

Kết quả men gan ALT, AST tăng cao cũng tương đồng với công bố Tag và cộng sự năm 2015 (Tag et al., 2015), Garrido và cộng sự năm 2017 (Garrido et al., 2017), Zhen và cộng sự năm 2015 (Zhen et al., 2015), Lang và cộng sự năm 2018 (Lang et al., 2018), Ale-Ebrahim và cộng sự (2015) (Ale-Ebrahim et al., 2015), Hargrove và cộng sự (2017) (Laura Hargrove et al., 2017), Shin và cộng sự (2017) (Seung Kak Shin et al., 2017), Eshraghi và cộng sự (2015) (Eshraghi, Eidi, Mortazavi, Asghari, \& Tavangar, 2015). Tắc mật sau 21 ngày phẫu thuật BDL, ALB ở chuột $\mathrm{BDL}$ giảm so với chuột bình thường $(\mathrm{P}<0,001)$ (Eshraghi et al., 2015).

Kết quả mô học $H \& E$ trong nghiên cứu này tương tự với các công bố của Shin và cộng sự (2017) (Seung Kak Shin et al., 2017), nhuộm H\&E của gan từ mô hình tổn thương mãn tính cho thấy thâm nhiễm tế bào viêm gia tăng với hoại tử bắc cầu và sự xen kẽ của dãy sợi $(\mathrm{S}$. $\mathrm{K}$. Shin et al., 2017). Công bố của L. Hargrove và cộng sự (2017) (Laura Hargrove et al., 2017), chuột BDL có biểu hiện tăng hoại tử, viêm vùng cửa, sự gia tăng hầu hết các ống mật lớn cũng được quan sát thấy sau BDL (L. Hargrove et al., 2017).

Kết quả nhuộm Sirius Red cho thấy sự tương đồng với công bố của Garrido và cộng sự (2017) (Garrido et al., 2017), Vartak và cộng sự (2016) (Vartak et al., 2016), Yang và cộng sự (2017) (Yang et al., 2015), Eshraghi và cộng sự (2015) (Eshraghi et al., 2015), Shin và cộng sự (2017) (Seung Kak Shin et al., 2017) cho thấy kết quả nhuộm Sirius Red có sự tích tụ collagen ở nhóm BDL. Trong mô hình tổn thương cấp tính, mức độ dương tính collagen (\%) trong đối chứng và $\mathrm{BDL}$ lần lượt là $0.22 \pm 0.04 \%, 1.64 \pm 0.53 \%$ (S. K. Shin et al., 2017), diện tích collagen trên tổng diện tích mô gan trung bình là $2.5 \%$ ở nhóm đối chứng và $6.5 \%$ ở chuột $\mathrm{BDL}$ ở tuần thứ 2 ( $\mathrm{p}<0,001)$ (Garrido et al., 2017). Khi gan bị tổn thương, tế bào hình sao ở gan (hepatic stellate cells) sẽ chuyển sang dạng hoạt hóa dưới tác động của các phân tử tín hiệu gây viêm và chuyển dạng thành các nguyên bào sợi cơ (myofibroblast) tăng sinh nhanh và tăng tích lũy collagen (Ale-Ebrahim et al., 2015)

Trong 7 ngày đầu BDL, nguyên nhân chết của nhóm mô hình là do nhiễm trùng ổ bụng $3.64 \%$ (2/55), áp xe $1.82 \%$ (1/55), vỡ túi mật 5.45\% (3/55), nhiễm trùng huyết hoặc không rõ lý do $3.64 \%$ (2/55). Tỷ lệ sống của nhóm đối chứng là $100 \%$, tương đồng với nhiều nghiên cứu. Tỷ lệ sống của nhóm mô hình sau 7 ngày và 19 ngày phẫu thuật lần lượt là $85.45 \%$ và $66.67 \%$, cao hơn so với công bố của Yang và cộng sự năm 2015 (Yang et al., 2015), phẫu thuật BDL trên chuột cống, trọng lượng cơ thể $220-250 \mathrm{~g}$, nhóm đối chứng có tỷ lệ sống $100 \%$, nhóm tạo 
mô hình BDL có tỷ lệ tử vong là $42.5 \%$ (17/40). Đa số tử vong xảy ra trong hai tuần đầu tiên sau khi $\mathrm{BDL}$ và hầu hết các trường hợp tử vong là do vỡ ống mật hoặc rò rỉ mật, nhiễm trùng. Tỷ lệ sống của nhóm mô hình là $66.67 \%$, thấp hơn so với công bố Garrido và $C$. Escobar năm 2017 (Garrido et al., 2017), BDL chuột cống 3 tuần tuổi, khối lượng cơ thể 49.5g (48.3-55.6), nhóm đối chứng có tỷ lệ sống 100\% (21/21), nhóm tạo mô hình có tỷ lệ sống 90.5\% (19/21), thời gian thí nghiệm là 2-6 tuần. Công bố của Tag và cộng sự (Tag et al., 2015) phẫu thuật BDL 40 chuột nhắt đực có trọng lượng cơ thể $18-20 \mathrm{~g}$, tỷ lệ sống đạt $95 \%$ trong thời gian tiến hành thí nghiệm là 3-60 ngày.

Khi tiến hành cấy ghép MSC cho nhóm chuột Swiss BDL bước đầu ghi nhận có sự thúc đẩy quá trình phục hồi một phần chức năng gan và ức chế viêm gan thông qua việc giảm nồng độ men gan trong máu, cải thiện nồng độ Albumin, giảm kích thước gan, giảm vàng da (đuôi và tai) và giảm xơ trong mô gan. Tại thời điểm 12 ngày sau ghép, tỉ lệ sống sót của nhóm chuột thắt mật được điều trị với nhóm điều trị MSC $5 \times 10^{5} \mathrm{tb} / \mathrm{con}$ là $100 \%$. Kết quả men gan $\mathrm{ALT}$, AST giảm ở nhóm điều trị bằng MSC so với nhóm đối chứng cho thấy có hiệu quả giảm viêm, giảm sự hình thành các dãy xơ hóa ở gan, giảm AST và ALT, ổn định nồng độ Albumin huyết thanh, dấu hiệu gan được phục hồi. Các kết quả cũng cho thấy sự tương đồng với các nhóm nghiên cứu của Carvalho và cộng sự (2008) (Carvalho et al., 2008), Trương và cộng sự (N. H. Truong, Nguyen, et al., 2016), Cho và cộng sự (Kyung-Ah Cho et al., 2012) với công bố MSC bảo vệ tế bào gan bằng cách giảm thiệt hại ROS do TAA gây ra cả in vivo và in vitro, MSC vượt qua stress oxy hóa do $\mathrm{CCl}_{4}$. Kết quả nhuộm $\mathrm{H} \& \mathrm{E}$ và Sirius Red tương tự với công bố của Quintanilha và cộng sự (Quintanilha et al., 2014) và Gressner và cộng sự (Gressner, Weiskirchen, \& Gressner, 2007), MSC giúp giảm xơ gan như giảm vùng hoại tử (6.11\% so với nhóm mô hình là $13.14 \%$ ) và giảm sự tích tụ collagen (1.81\% so với nhóm mô hình là $2.83 \%)$, gen $\alpha$-SMA cũng giảm hoạt động (1.06\% so với nhóm đối chứng là 3.15\%). Kết quả đánh giá tại thời điểm ngày thứ 19 sau BDL (ngày thứ 12 sau khi tiêm MSC), chuột ở nhóm MSC cho thấy có sự giảm viêm gan, chức năng gan có cải thiện so với nhóm BDL-PBS.

Trên thế giới có rất nhiều dẫn chứng từ các công trình nghiên cứu cho thấy hiệu quả điều trị viêm gan từ các nguyên nhân khác nhau của MSC, từ các nguồn khác nhau như Zhao và cộng sự sử dụng BM-MSC cùng loài để điều trị xơ gan do $\mathrm{CCl}_{4}$ trên (Zhao et al., 2018), Cho và cộng sự nghiên cứu tiềm năng tái tạo mô gan của tế bào gốc trung mô. Gần đây nhất là Wanatabe và cộng sự năm 2019 (Watanabe et al., 2019) sử dụng MSC kết hợp với yếu tố kích thích đại thực bào factor-1 có nguồn gốc từ tủy xương để cải thiện và tái tạo xơ hóa ở gan. Shao và cộng sự năm 2020 (Shao et al., 2020) dùng exosome có nguồn gốc từ UCB-MSC để cải thiện tình trạng tổn thương gan cấp tính do IL-6 gây ra thông qua miR-455-3p. Angioni và cộng sự năm 2020 (Angioni et al., 2020) nghiên cứu dùng các túi ngoại bào (extracellular vesicles-Evs) từ tế bào gốc trung mô tủy xương người (BM-MSC) nhằm giảm viêm và xơ hóa gan ở chuột. Các công trình nghiên cứu này là tiên phong trong việc tiếp cận điều trị bệnh gan từ MSC. Trong nghiên cứu điều trị tình trạng tắc mật trên chuột bằng liệu pháp tế bào gốc trung mô của chúng tôi cũng cho các kết quả tạo tiền đề để các nghiên cứu tiếp theo sâu hơn về chứng minh cơ chế điều trị và mở ra triển vọng cho điều trị tồn thương gan nói chung và tổn thương gan do tắc mật nói riêng.

\section{Kết luận và gọi ý}

Trong giới hạn của nghiên cứu, việc ghép MSC trên chuột tắc mật có tính an toàn, cải thiện tỉ lệ sống của chuột (sau 12 ngày ghép). Tiêm MSC cải thiện chức năng gan, giảm tình trạng viêm, hoại tử và xơ hoá gan trên mô hình chuột tổn thương gan do tắc mật. 


\section{LÒ̀I CẢM ONN}

Nghiên cứu này được tài trợ bởi Quỹ Phát triển khoa học và công nghệ Quốc gia (NAFOSTED) trong đề tài mã 108.05-2017.30.

\section{Tài liệu tham khảo}

Ale-Ebrahim, Mahsa Eidi, Akram Mortazavi, Pejman Tavangar, S. M. T., \& Minai, D. (2015). Hepatoprotective and antifibrotic effects of sodium molybdate in a rat model of bile duct ligation. Journal of Trace Elements in Medicine and Biology, 29, 242-248.

Angioni, R., Calì, B., Vigneswara, V., Crescenzi, M., Merino, A., Sánchez-Rodríguez, R., Viola, A. (2020). Administration of Human MSC-Derived Extracellular Vesicles for the Treatment of Primary Sclerosing Cholangitis: Preclinical Data in MDR2 Knockout Mice. Molecular Sciences, 21(22).

Bates, M. D., Bucuvalas, J. C., Alonso, M. H., \& Ryckman, F. C. (1998). Biliary atresia: pathogenesis and treatment. Semin Liver Dis, 18(3), 281-293.

Carvalho, A. B., Quintanilha, L. F., Dias, J. V., Paredes, B. D., Mannheimer, E. G., Carvalho, F. G., Resende, C. M. C. (2008). Bone marrow multipotent mesenchymal stromal cells do not reduce fibrosis or improve function in a rat model of severe chronic liver injury. Stem Cells, 26(5), 1307-1314.

Castillo, M., Liu, K., Bonilla, L., \& Rameshwar, P. (2007). The immune properties of mesenchymal stem cells. Int J Biomed Sciences, 3(2), 76-80.

Cho, K. A., Ju, S.-Y., Cho, S. J., Jung, Y.-J., Woo, S.-Y., Seoh, J.-Y., Ryu, K.-H. (2009). Mesenchymal stem cells showed the highest potential for the regeneration of injured liver tissue compared with other subpopulations of the bone marrow. Cell Biology International, 33(7), 772-777.

Cho, K. A., Woo, S. Y., Seoh, J. Y., Han, H. S., \& Ryu, K. H. (2012). Mesenchymal stem cells restore CC14-induced liver injury by an antioxidative process. Cell Biology International, 36(12), 1267-1274.

Eom, Y. W., Shim, K. Y., \& Baik, S. K. (2015). Mesenchymal stem cell therapy for liver fibrosis. Korean J Intern Med, 30(5), 580-589.

Eshraghi, T., Eidi, A., Mortazavi, P., Asghari, A., \& Tavangar, S. M. (2015). Magnesium protects against bile duct ligation-induced liver injury in male Wistar rats. Researchgate, 28(1), 32-45.

Garrido, M., Escobar, C., Zamora, C., Rejas, C., Varas, J., Párraga, M., Montedónico, S. (2017). Bile duct ligature in young rats: A revisited animal model for biliary atresia. European journal of histochemistry : EJH, 61(3), 2803-2803.

Gressner, O. A., Weiskirchen, R., \& Gressner, A. M. (2007). Evolving concepts of liver fibrogenesis provide new diagnostic and therapeutic options. Comparative hepatology, $6(1), 1-13$.

Hargrove, L., Kennedy, L., Demieville, J., Jones, H., Meng, F., DeMorrow, S., Francis, H. (2017). Bile duct ligation-induced biliary hyperplasia, hepatic injury, and fibrosis are reduced in mast cell-deficient KitW-sh mice. Hepatology, 65(6), 1991-2004.

Jin, H. J., Bae, Y. K., Kim, M., Kwon, S.-J., Jeon, H. B., Choi, S. J., Chang, J. W. (2013). Comparative analysis of human mesenchymal stem cells from bone marrow, adipose tissue, and umbilical cord blood as sources of cell therapy. Int J Mol Sci, 14(9), 1798618001. 
Kountouras, J., Billing, B. H., \& Scheuer, P. J. (1984). Prolonged bile duct obstruction: a new experimental model for cirrhosis in the rat. Br J Exp Pathol, 65(3), 305-311.

Lang, E., Pozdeev, V. I., Shinde, P. V., Xu, H. C., Sundaram, B., Zhuang, Y., Lang, P. A. (2018). Cholestasis induced liver pathology results in dysfunctional immune responses after arenavirus infection. Scientific Reports, 8(1), 12179.

Liu, M. B., Huong, T. B., Hoang, X., Doan, L., Trinh, S., Anh Nguyen, H. P., Holterman, A. X. (2017). Biliary atresia in Vietnam: Management and the burden of disease. Surgery, 161(2), 533-537.

Liu, T., Wang, X., Karsdal, M. A., Leeming, D. J., \& Genovese, F. (2012). Molecular serum markers of liver fibrosis. Biomark Insights, 7, 105-117.

Lou, G., Chen, Z., Zheng, M., \& Liu, Y. (2017). Mesenchymal stem cell-derived exosomes as a new therapeutic strategy for liver diseases. Exp Mol Med, 49(6), e346.

Nam, Y., Ko, S. K., \& Sohn, U. D. (2019). Hepatoprotective effect of ultrasonicated ginseng berry extract on a rat mild bile duct ligation model. Journal of Ginseng Research, 43(4), 606-617.

Quintanilha, L. F., Takami, T., Hirose, Y., Fujisawa, K., Murata, Y., Yamamoto, N., Sakaida, I. (2014). Canine mesenchymal stem cells show antioxidant properties against thioacetamide-induced liver injury in vitro and in vivo. Hepatology Research, 44(10), E206-E217.

Shao, M., Xu, Q., Wu, Z., Chen, Y., Shu, Y., Cao, X., Yao, R. (2020). Exosomes derived from human umbilical cord mesenchymal stem cells ameliorate IL-6-induced acute liver injury through miR-455-3p. Stem cell researchtherapy, 11(1), 1-13.

Shin, S. K., Kwon, O. S., Lee, J. J., Park, Y. H., Choi, C. S., Jeong, S. H., Kim, J. H. (2017). Effect of Rifaximin on Hepatic Fibrosis in Bile Duct-ligated Rat Model. The Korean journal of gastroenterology, 70(5), 239-246.

Shin, S. K., Kwon, O. S., Lee, J. J., Park, Y. H., Choi, C. S., Jeong, S. H., Kim, J. H. (2017). Effect of Rifaximin on Hepatic Fibrosis in Bile Duct-ligated Rat Model. Korean J Gastroenterol, 70(5), 239-246.

Shinkai, M., Ohhama, Y., Take, H., Kitagawa, N., Kudo, H., Mochizuki, K., \& Hatata, T. (2009). Long-term outcome of children with biliary atresia who were not transplanted after the Kasai operation: >20-year experience at a children's hospital. J Pediatr Gastroenterol Nutr, 48(4), 443-450.

Tag, C. G., Sauer-Lehnen, S., Weiskirchen, S., Borkham-Kamphorst, E., Tolba, R. H., Tacke, F., \& Weiskirchen, R. (2015). Bile duct ligation in mice: induction of inflammatory liver injury and fibrosis by obstructive cholestasis. Journal of visualized experiments: JoVE(96).

Truong, G. D., Van, T. N., Anh, T. T. T., Binh, A. N., Tien, S. B., Tuan, K. L., Tien, T. N. (2018). Kết quả nghiên cứu bước đầu sử dụng tế bào gốc tủy xương tự thân trong điều trị xơ gan mất bù do virus viêm gan B. Tạp chí Y Dược lâm sàng, 13(7), 109-115.

Truong, N. H., Nguyen, N. H., Le, T. V., Vu, N. B., Huynh, N., Nguyen, T. V., Pham, P. V. (2016). Comparison of the Treatment Efficiency of Bone Marrow-Derived Mesenchymal Stem Cell Transplantation via Tail and Portal Veins in CC14 - Induced Mouse Liver Fibrosis. Stem Cells Int, 2016, 5720413.

Truong, N. H., Trình, L. V., Nam, N. H., Phúc, P. V., Ngọc, P. K., Đạt, N. Q., Thanh, N. V. (2016). Đánh giá hiệu quả điều trị xơ gan của việc ghép tế bào gốc trung mô tủy xương trên mô hình chuột. Tạp chí Khoa học và Công nghệ Việt Nam, 4(4). 
Ullah, I., Subbarao, Raghavendra B., \& Rho, Gyu J. (2015). Human mesenchymal stem cells current trends and future prospective. Bioscience Reports, 35(2).

Vartak, N., Damle-Vartak, A., Richter, B., Dirsch, O., Dahmen, U., Hammad, S., \& Hengstler, J. G. (2016). Cholestasis-induced adaptive remodeling of interlobular bile ducts. Hepatology, 63(3), 951-964.

Wang, M., Yuan, Q., \& Xie, L. (2018). Mesenchymal Stem Cell-Based Immunomodulation: Properties and Clinical Application. Stem Cells Int, 2018, 3057624.

Watanabe, Y., Tsuchiya, A., Seino, S., Kawata, Y., Kojima, Y., Ikarashi, S., Kawai, H. (2019). Mesenchymal stem cells and induced bone marrow-derived macrophages synergistically improve liver fibrosis in mice. Stem cells translational medicine, 8(3), 271-284.

Yang, Y., Chen, B., Chen, Y., Zu, B., Yi, B., \& Lu, K. (2015). A comparison of two common bile duct ligation methods to establish hepatopulmonary syndrome animal models. Laboratory animals, 49(1), 71-79.

Zhao, M., Li, P., Xu, H., Pan, Q., Zeng, R., Ma, X., Lin, H. (2018). Dexamethasone-Activated MSCs Release MVs for Stimulating Osteogenic Response. Stem Cells Int, 2018, $7231739-7231739$.

Zhen, Y.-Z., Li, N.-R., He, H.-W., Zhao, S.-S., Zhang, G.-L., Hao, X.-F., \& Shao, R.-G. (2015). Protective effect of bicyclol against bile duct ligation-induced hepatic fibrosis in rats. World journal of gastroenterology, 21(23), 7155-7164. 